\title{
Seni Pertunjukan Teater Asera Berdasarkan Mitos To Balo, Suku Bentong Sulawesi Selatan
}

\author{
Prusdianto $^{1}$ \\ Program Pascasarjana, Institut Seni Indonesia Yogyakarta
}

\begin{abstract}
ABSTRAK
Teater tentang absurditas dengan paradoksnya yang aneh merupakan sebuah gejala dari apa yang mungkin paling mendekati pencarian relijius murni, yaitu suatu usaha manusia menyadari realitas mutlak kondisinya, dan mengajarkan kembali kepadanya makna keajaiban kosmis yang hilang dan kegalauan purba. Penciptaan pertunjukan teater Asera mengambil ide tentang kematian yang ditentukan oleh jumlah Sembilan. Ide tersebut terinspirasi dari mitos yang ada pada To Balo, suku Bentong yang berada di Sulawesi Selatan. Hal yang mendasari penciptaan Asera ini adalah keinginan untuk mengangkat sebuah permasalahan yang mengingatkan kita akan kematian. Sebuah proses dalam kehidupan yang sebenarnya mutlak akan dialami oleh manusia, akan tetapi sering dilupakan keberadaanya. Selain menjadikan warisan mitos sebagai sumber ide penciptaan, juga memberikan warna dan corak baru dalam dunia seni, khususnya seni teater. Teater adalah dunia imajinasi dari kehidupan yang sebenarnya.
\end{abstract}

Kata kunci: Teater, Asera, absurd, To Balo, Bentong.

\begin{abstract}
The Performing Arts of theater Asera based on the myth of To Balo, Bentong tribe South Sulawesi. The absurdity of theatre with its weird paradox is as a phenomenon of what is probably as the closest quest to the purity of religiousity that is a human's effort to realize the reality of his absolute condition, and to teach him back the meaning of the missing remarkable cosmic and the ancient confusion. The creation of theater performance Asera takes an idea of death which has been decided by number nine. This idea was first inspired from a myth that exists in To Balo, a Bentong tribe lives in South Sulawesi. The basic creating idea of Asera is a willingness to discuss a problem that reminds us to the death. A process in a real life will be absolutely experienced by man, but its existence will often be forgotten. In addition to making a myth heritage as a source of creating ideas, it also gives the new colours and characteristics in the world of arts, especially in the art of theater. However, theater is the real life imagination.
\end{abstract}

Keywords: Theatre, Asera, absurd, To Balo, Bentong.

\section{Pendahuluan}

Asera adalah judul dari naskah lakon dan karya seni pertunjukan teater yang berasal dari bahasa Bugis yang berarti Sembilan, salah satu bilangan dalam angka. Karya pertunjukan teater Asera ini diciptakan dengan menggambarkan sebuah situasi yang dialami oleh manusia dalam memandang kematian. Kematian yang terjadi sebagai akibat dari adanya proses kelahiran yang dibatasi oleh jumlah sembilan. Penciptaan karya Asera menghadirkan hanya sembilan orang tokoh. Kelahiran seorang bayi pada kehidupan mereka akan menimbulkan kematian, sehingga jumlah tokoh-tokoh tersebut tidak bisa melebihi jumlah angka sembilan. Keadaan ini menjadikan kematian sebagai sesuatu hal yang dapat direncanakan kedatangannya.

Karya seni lahir dari manusia yang memiliki visi estetika dan diwujudkan dalam sebuah media ungkap untuk mempresentasikan halhal yang merupakan wujud dari kreasi intuisi diri dan kehidupannya (Sudaryanto, 2004:246). Penciptaan pertunjukan teater Asera mengambil ide tentang kematian yang ditentukan oleh jumlah Sembilan. Ide tersebut terinspirasi dari mitos yang ada pada To Balo, suku Bentong yang berada di Sulawesi Selatan. Hal yang mendasari penciptaan Asera ini adalah keinginan untuk mengangkat sebuah permasalahan yang mengingatkan kita akan kematian. Sebuah proses dalam kehidupan yang sebenarnya mutlak akan dialami oleh manusia, akan tetapi sering dilupakan keberadaanya. Kematian yang menandai akhir dari kebebasan manusia, menjadi satu pokok permasalahan yang sering dibahas oleh filsuf-filsuf eksistensialisme.

Friedrich Wilhem Nietzsche (1844-1900) yang telah membunuh 'Tuhan' melalui pahamnya,

1 Alamat korespondensi: Jalan Nelayan II No. 26, Kupa, Maliusetasi, Kab. Barru, Sulawesi Selatan 90753. HP. 08976899740.

Email: prusdianto@yahoo.com 
mengajak manusia untuk hidup tanpa 'Tuhan' dan menghadapi kenyataan dengan lapang dada. Nietszche memahami kematian adalah sesuatu hal yang harus diputuskan oleh diri sendiri sebagai manusia. Hal ini terlihat dari kutipan Nietzche (1977:136) dalam Thus Spake Zarathustra; "Kematianku, aku memuji engkau, kematian yang bebas, yang datang padaku karena aku menginginkannya. Bebas untuk mati dan bebas dalam maut, mampu untuk mengatakan "tidak" dengan ikhlas bilamana kesempatan mengatakan "ya" telah lewat.

Martin Heidegger (1889-1976) yang juga salah satu tokoh eksistensialisme, menyatakan bahwa keberadaan manusia yang temporal berada di luar ketidakadaan dilingkupi dan dibatasi oleh waktu (O'donnel, 2003:135). Terbukti dari kenyataan bahwa dia dilemparkan - tanpa pilihannyake dalam kematian dan di belakangnya selalu menyertai bayangan akan ketiadaan-nya. Segera setelah kelahirannya, manusia sudah cukup tua untuk mengalami kematian. Keberadaan manusia merupakan keberadaan menuju mati (beingto wards death). Bagi Heidegger, kematian seyogyanya tidak hanya diartikan sebagai berhentinya kehidupan atau dalam proses menuju akhir. Proses kematian adalah cara berada yang diterima manusia segera setelah kelahirannya.

Jean Paul Sartre (1905-1980) mengatakan, "Kematian menyingkirkan semua makna dari kehidupan". Bagi Sartre kematian tak dapat diangkat dengan diintegrasikan dalam perencanan eksistesial manusia. Dalam arti itu kematian bukanlah dimensi konstitutif eksistensi. Garis hidup manusia tidak dapat dikatakan sebagai perjalanan menuju kematian, apalagi sebagai penantian (erwaten) kematian. Manusia hanya menunggu fakta bahwa ia harus mati tetapi tidak pernah mengharapkan kematian. Setiap orang menemukan dirinya dalam kondisi yang sama yaitu "terkutuk" untuk mati (Muzairi, 2002:164).

Albert Camus (1913-1960) mengatakan bahawa kematian sebagai pokok alasan mengapa manusia senantiasa tenggelam pada penderitaan dan ketakutan sehingga tidak pernah dapat bebas secara mutlak untuk mengeksistensikan dirinya (Camus, 1999:18). Manusia mati, oleh karena itu ia tidak bahagia, lebih jauh lagi bahwa manusia tidak mampu menjabarkan hakikat kematiannya sendiri karena rasionya yang terbatas. Kematian disebut Camus sebagai absurditas yang puncak Hidup menjadi kehilangan makna (absurd) karena manusia tidak pernah mampu mewujudkan kehendaknya secara bebas.

\section{Kematian: Mitos Angka Sembilan To Balo}

Legenda bersifat sekuler (keduniawian), terjadinya pada masa yang belum begitu lampau, dan bertempat di dunia seperti yang kita kenal sekarang (Dananjaja, 1984:66). Salah satu contoh legenda yang mengisahkan tentang kematian dapat kita temukan pada masyarakat Suku Bentong. Suku Bentong merupakan salah satu suku terasing yang berada di Sulawesi Selatan. Suku tersebut tinggal di tempat terpencil di perbatasan kabupaten Pangkep dan Barru, secara administratif daerah mereka masuk dalam wilayah kabupaten Barru. Keunikan Suku Bentong ini adalah karena di dalam anggota masyarakatnya terdapat beberapa orang yang memiliki kulit yang tidak lazim seperti orang-orang normal pada umumnya. Sekujur tubuh mereka belang, terutama kaki, dada, dan tangan penuh bercak putih. Sementara tepat di tengah dahi mereka, bercak tersebut juga terpampang nyaris membentuk segitiga. Masyarakat Bentong menyebut mereka To Balo yang dalam artinya adalah manusia belang atau orang belang (Longi, 2003:5).

Menurut Abu Hamid, Budayawan Sulawesi Selatan yang pernah melakukan penelitian tentang To Balo. bahwa kelainan kulit yang dialami

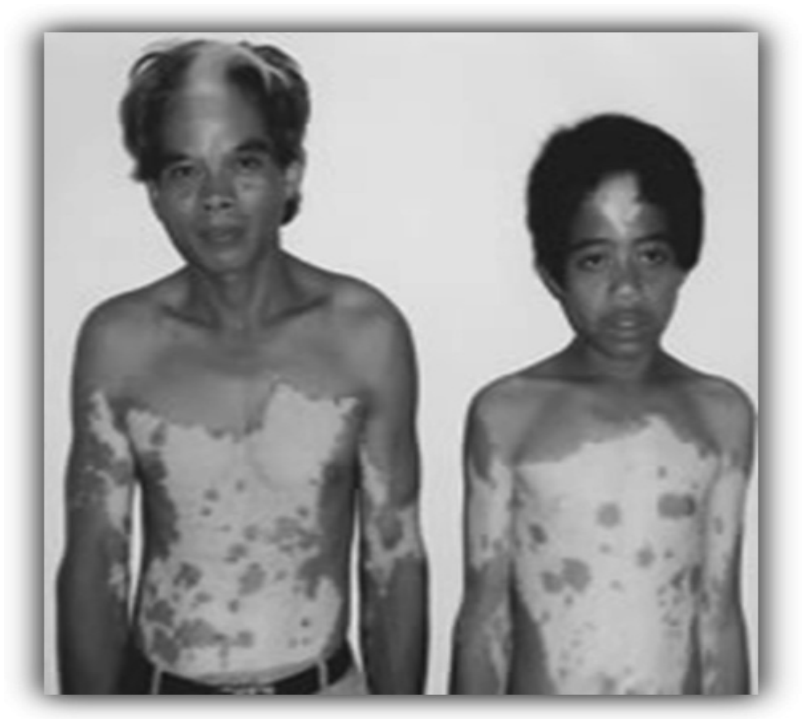

Gambar 1. Masyarakat To Bolo (sumber: www.sosbud. kompasiana.com) 
To Balo di desa Bulo-Bulo, bukanlah penyakit melainkan pembawaan gen. Banyak pula versi yang berkembang di desa tersebut tentang asalusul dari To Balo. Ada yang menganggap bahwa hal tersebut sebagai kutukan, karena melanggar sesuatu yang dipesankan pendahulunya. Menurut Nurdin Dg. Matutu, Pemuka masyarakat Bentong, bahwa asal-usul To Balo diawali ketika Datu Tanete dari Kerajaan Tanete mengundang Arung Bontotiro karena adanya rencana perlawanan kerajaan Tanete kepada Belanda.

Bulo-Bulo yang menjadi bagian dari wilayah kerajaan Tanete membuat Arung Bontotiro memenuhi undangan Datu Tanete di Pancana. Pada waktu itu, Datu Tanete meminta kepada Arung Bontotiro mengirim 30 orang pemberani dari Bulo-Bulo untuk berperang melawan Belanda di pulau Putianging. Setibanya kembali di Bulo-Bulo, Arung Bontotiro mengumpulkan pemberaninya. Salah seorang pemberani yang bernama I Pundeng berkeinginan memenuhi undangan Datu Tanete, namun karena usianya sudah lanjut maka ia menunjuk anaknya yang bernama I Untung. Sang anak menyetujuinya tapi merasa tidak memiliki kemampuan seperti pemberani, dari Sang ayah kemudian memberikan bekal Pakaian To Bura'ne yang merupakan ilmu kekebalan.

Dari 30 pemberani yang diminta Datu Tanete hanya sembilan orang yang berangkat termasuk I Untung. Sebelum mereka berangkat I Pundeng juga memberikan ilmu kebal sama seperti yang dia berikan kepada I Untung kepada yang lainnya, di samping nasihat dan petuah tentang apa yang harus dilakukan dan apa yang tidak boleh dilanggar (Longi, 2003:12).

Setelah tiga tahun berperang membela kerajaan Tanete, ke-sembilan pemberani tersebut pulang ke Bulo-bulo. Pesan I Pundeng untuk memotong ayam sebagai tumbal sebelum naik ke rumah panggung tidak dilaksanakan, mereka begitu saja naik ke rumah panggung karena terlalu rindu kepada sanak keluarganya. Setelah itu seketika kulit mereka berubah menjadi belang. Kutukan itu juga menjadikan keturunan-keturunan mereka kelak yang berkulit belang tidak bisa berjumlah lebih dari sembilan orang. Mereka akan tetap tidak bisa berjumlah lebih dari sembilan orang, sehingga apabila ada yang lahir pada saat mereka berjumlah sembilan orang, akan diikuti oleh kematian salah seorang diantara mereka.
Berdasarkan kisah di atas kemudian dijadikan sebagai ide untuk naskah dan pertunjukan teater Asera. Kelahiran menjadi konsekuensi dari kematian ketika sudah berada pada jumlah sembilan. Kematian menjadi sebuah ancaman pada kesembilan orang tersebut, akibat akan adanya proses kelahiran. Tokoh-tokoh dalam cerita nantinya akan mengalami situasi yang dilematis, mereka melihat kematian begitu sangat dekat menghampiri diri dan orang-orang terdekatnya. Pilihan ada pada diri sendiri, apakah ikut larut pada kematian yang mengatur mereka ataukah melakukan sebuah tindakan yang lain.

Judul naskah dan pertunjukan teater ini adalah Asera. Asera yang berarti Sembilan dalam bahasa Bugis mewakili secara keseluruhan ide dan peristiwa dari penciptaan naskah dan pertunjukan teater ini. Sebuah angka yang mengatur jumlah, kelahiran menjadi situasi yang memungkinkan kematian bisa terjadi.

Naskah drama Asera menggambarkan sebuah situsasi yang menempatkan posisi tokoh-tokoh sebagai sebuah situasi, keadaan, ketidaksetiaan terhadap realitas mutlak kondisinya. Empat orang tokoh sebagai penutur dialog dalam cerita, yaitu; Rakdak, Jaru, Nuru dan Tawang. Lima tokoh lainnya sebagai simbol dari keterikatan mereka terhadap jumlah sembilan, yaitu; Pundeng, Nanna, Kama, Rannu dan Pammase. Kejadian berlangsung dalam sebuah rumah dengan peristiwa waktu yang berubah-ubah.

Sebagian besar cerita dari lakon Asera ini menceritakan situasi yang dialami oleh Rakdak sebagai tokoh utama. Kematian ibunya pada saat dia dilahirkan, kematian bapaknya yang dibarengi dengan kelahiran anak dari Rannu, menempatkan dirinya dalam sebuah kondisi yang menurutnya adalah sebuah pemberian takdir tragis. Sebuah kejadian (kematian Jaru bersamaan denga kelahiran bayi Rannu) yang kemudian menjadi titik tolak penentuan takdir bagi Rakdak. Rakdak mulai meyakini bahwa jumlah sembilan yang mengatur mereka benar-benar terjadi dan membawa tiap-tiap individu lebih dekat dengan kematian serta mengancam keberadaan orangorang yang dicintainya sendiri.

Kehilangan orang-orang yang dicintai karena kematian menjadi sebuah situasi yang mempengaruhi dan mendominasi sikap Rakdak. Sebuah sikap cinta yang akut, sikap yang me- 
nolak kehilangan. Hal ini tergambarkan ke dalam situasi ketika Rakdak memutuskan untuk melarang isterinya Nuru ke luar rumah. Sebuah pilihan yang dilakukan Rakdak untuk menjaga peluang agar tetap bersama, pilihan yang menurut dirinya adalah sebuah pilihan yang tepat, tidak membiarkan orang lain tahu akan kehamilan yang dialami oleh isterinya.

Situasi berikutnya adalah aplikasi dari sikap benci, usaha agar bebas dan terjamin. Kematian Jaru menempatkan Rakdak, Nuru dan Tawang dalam posisi yang mengancam ke-ada-an masingmasing, dengan membunuh yang lain di luar mereka bertiga sebagai sebuah alasan untuk membebaskan diri siklus jumlah sembilan tersebut yang semakin menempatkan mereka untuk menghilangkan ke-ada-an yang lainnya.

\section{Penciptaan Teater Asera: Konsep dan Perwujudannya}

Untuk mewujudkan pertunjukan teater Asera, berikut ini beberapa konsep dari unsur-unsur pertunjukan teater yang akan diwujudkan dalam penciptaan ini.

\section{Naskah}

Naskah lakon Asera menggambarkan sebuah situsasi yang menempatkan posisi tokoh-tokoh sebagai sebuah situasi, keadaan, ketidaksetiaan terhadap realitas mutlak kondisinya. Posisi mendekatkan diri kepada kematian akibat keterikatan dari jumlah sembilan menjadi titik tolak para tokoh untuk terus mewujudkan eksistensinya sebagai individu bebas.

Sebagian besar cerita dari lakon Asera ini menceritakan situasi yang dialami oleh Rakdak sebagai tokoh utama. Beberapa peristiwa kematian yang dialami oleh orang-orang terdekat Rakdak membuat sebuah frame pemikiran sendiri bagi dirinya. Kematian ibunya pada saat dia dilahirkan, kematian bapaknya yang dibarengi dengan kelahiran anak dari Rannu, menempatkan dirinya dalam sebuah

\section{Penyutradaraan}

Sutradara adalah pihak yang paling kritis dalam menghadapi sebuah naskah. Sutradara menjadikan naskah lakon bagaikan sebuah partitur musik di tangan seorang dirgen. Mewujudkan kenyataan naskah menjadi pertunjukan, naskah akan mengalami proses transformasi yang cukup panjang dan unik (Anirun, 2002:59). Pada proses transformasi dari naskah menuju pertunjukan, penulis menggunakan metode penyutradaraan dari Suyatna Anirun (2002:115-118) sebagai landasan konsep kerja penyutradaraan, yaitu; (1) tahap mencari-cari, (2) tahap memberi isi, (3) tahap pengembangan, (4) tahap pemantapan, (5) latihan umum (rehearsal).

\section{Pemeranan (Keaktoran)}

Kedirian diri salah satu motivasi yang digunakan dalam pertunjukan teater Asera ini. Kedirian diri yang dimaksud di sini adalah bukan tentang konfrontasi antara aktor dengan kehidupan dan lingkungannya dalam sebuah peristiwa, tetapi lebih kepada efek yang dialami oleh aktor terhadap kehidupan lingkungannya dalam sebuah situasi, sehingga menghadirkan kesunyian, kesepian, kegamangan dalam situasi absurd. Aktor dituntun untuk menjadi subjek dari naskah bukan menjadi objek dari naskah itu sendiri, berusaha untuk selalu menempatkan diri di luar (bukan ke luar) dari peristiwa.

\section{Penonton}

Tujuan terakhir suatu pertunjukan teater adalah penonton. John E. Dietrich mengemukakan bahwa, "drama adalah cerita konflik manusia dalam bentuk dialog yang diproyeksikan pada pentas dengan menggunakan percakapan dan action di hadapan penonton" (dalam Harymawan, 1988:193). Penonton sering dipandang sebelah matadalamsebuah pertunjukan teater. Kebanyakan proses penciptaan lebih memfokuskan diri kepada konsep dalam merangkai elemen-elemen seni tanpa memperhatikan penonton sebagai salah satu unsur penting dalam teater.

Pada pertunjukan assera ini, tujuan yang ingin dilakukan kepada penikmat adalah menghindari proses katarsis, lebih kepada penekanan kepada penonton untuk memilih sendiri keputusannya dari pertanyaan-pertanyaan yang ditimbulkannya sendiri pada saat melihat pertunjukan ini, sesuai dengan konsep teater tentang absurditas. 


\section{Artistik}

\section{a. Tata Kostum}

Kostum yang digunakan adalah kostum seharihari yang digunakan oleh masyarakat di Sulawesi Selatan (mewakili Makassar, Bugis, Mandar, Bentong) dalam lingkungan tradisional mereka. Sarung merupakan sesuatu hal yang tak bisa dipisahkan dari masyarakat Sulawesi Selatan baik yang berprofesi sebagai petani maupun nelayan.

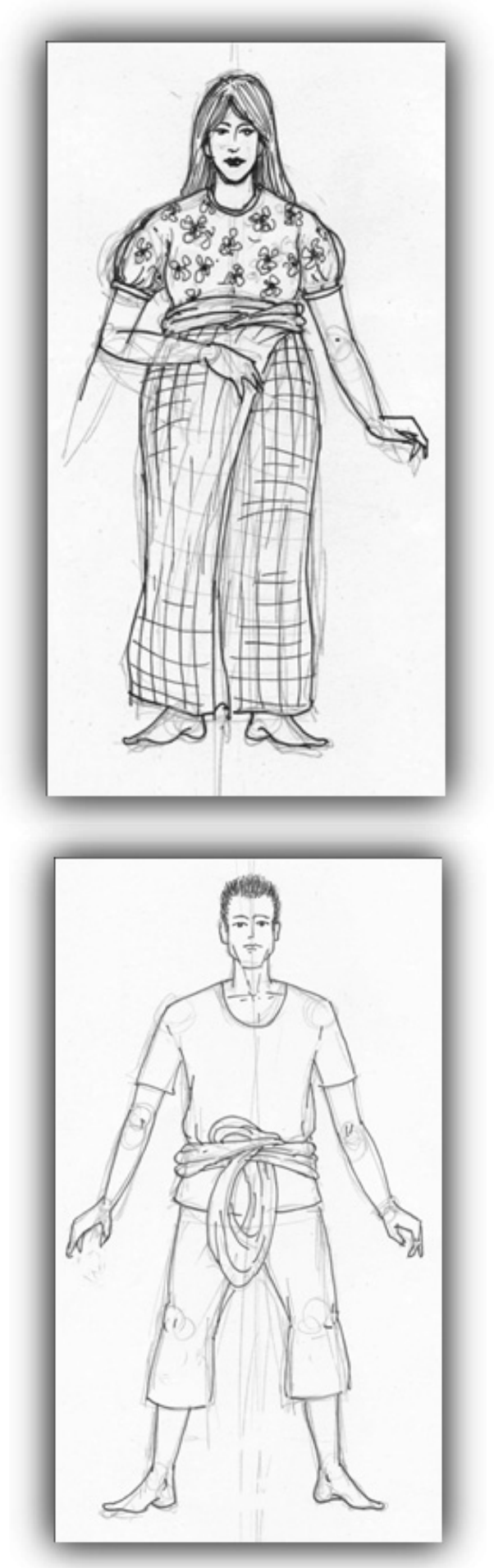

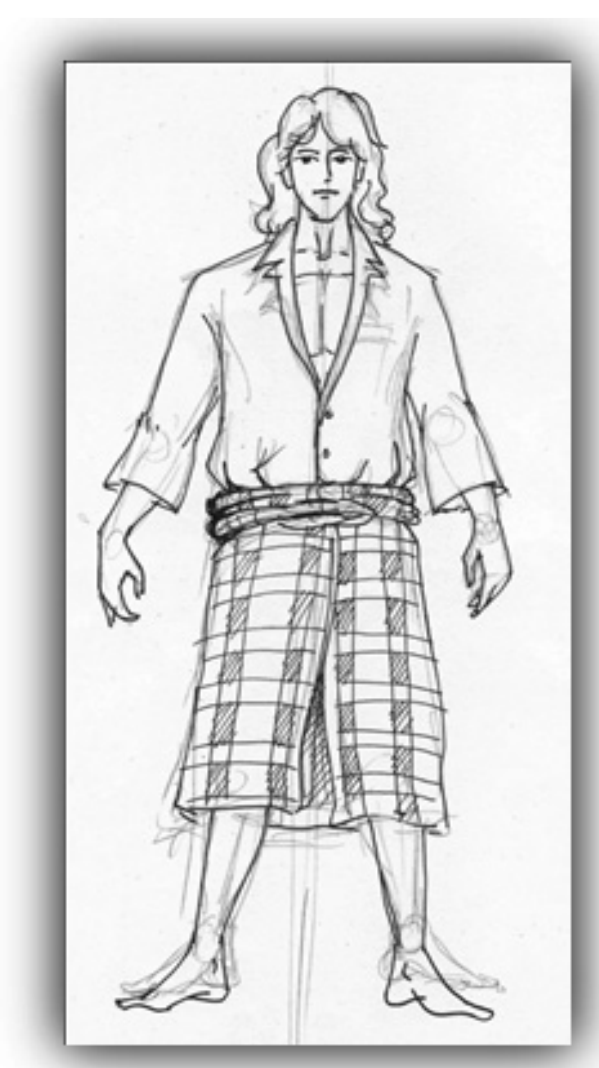
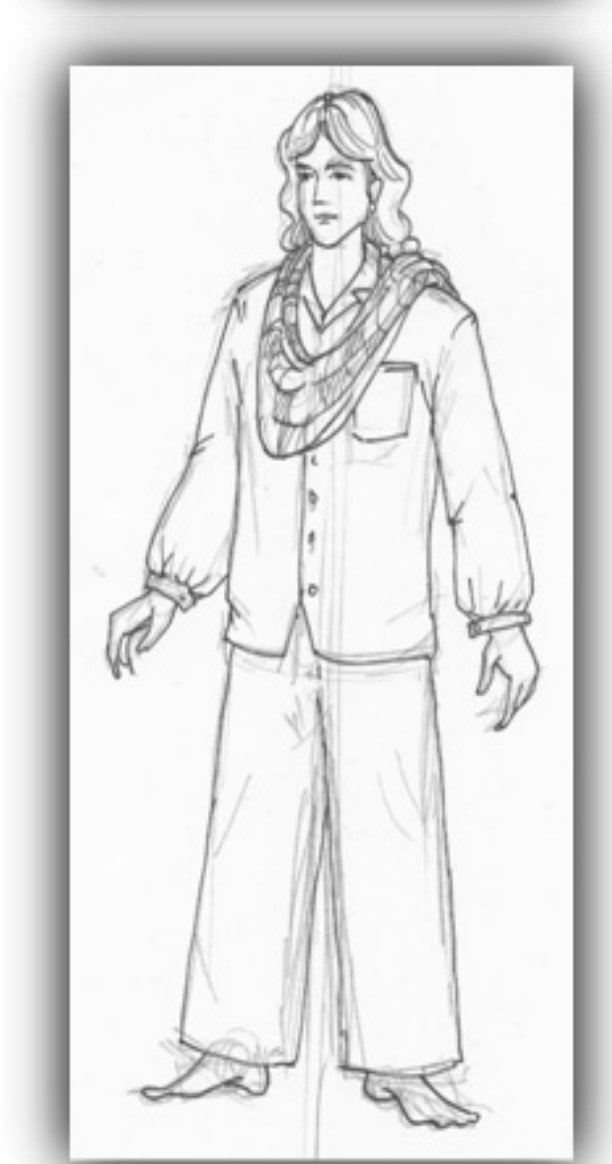

Gambar 2. Rancangan Kostum Rakdak, Nuru, Jaru dan Tawang (Desain: Ramdani Mangkualam. Gambar: Sally N Ardiansyah) 


\section{b. Tata Rias}

Rias yang digunakan pada pertunjukan Asera ini adalah rias realis, mempresentasikan masyarakat To Balo dalam kehidupan sehari-hari mereka. Rias usia, digunakan untuk menggambarkan umur yang sesuai dengan umur tokoh. Rias Karakter, secara keseluruhan pada tiap tokoh dengan memberikan identitas (efek belang pada kulit) sebagai simbol berada dalam satu lingkaran takdir.

\section{c. Tata Musik}

Musik yang hadir dalam pertunjukan Asera ini terdiri dari musik yang dibangun berdasarkan musik tema, musik illustrasi dan sound effect. Tiaptiap musik berfungsi untuk menegaskan suasana yang ingin dicapai dalam setiap adegan.

\section{d. Tata Cahaya}

Memberikan suasana latar dan situasi yang terdapat pada adegan-adegan dalam naskah. Suasana pada pertunjukan Asera, menggambarkan suasana mencekam dalam kecemasan melihat kematian sebagai suatu yang mengancam.

Tata cahaya pertunjukan Asera, memiliki empat bagian khusus yang menjadi peralihan dalam mengantar dan membangun suasana dalam pertunjukan, selain dari itu kesemua lampu digunakan oleh penata lampu sebagai pelengkap untuk membantu bagian-bagian tersebut.

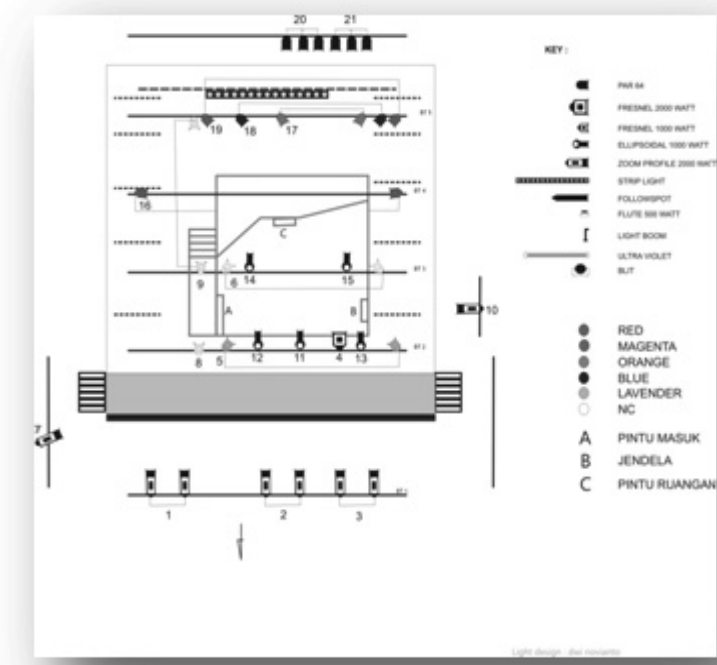

Gambar 3. Lighting Design pertunjukan Asera Desain dan Penata Cahaya: Dwi Novianto (Foto: Dwi Novianto)

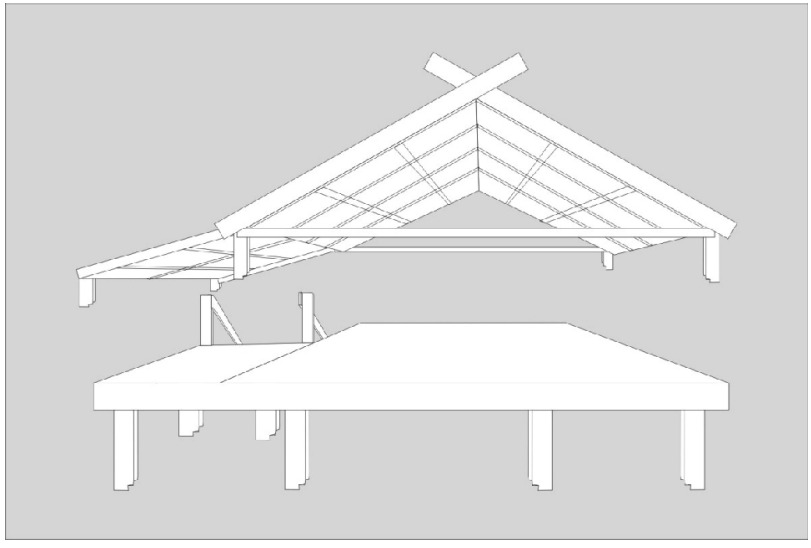

Gambar 4. Setting Rumah Panggung Pertunjukan Asera (Desain: Gajah Mada)

\section{e. Tata Panggung dan Komposisinya}

Setting yang digunakan adalah setting realis, presentasi dari rumah panggung yang ada di Sulawesi Selatan. Realis yang digunakan adalah tidak menghadirkan secara utuh rumah panggung yang dimaksud, tetapi realis yang sugestif, menghadirkan bagian-bagian dari rumah, seperti atap, lantai, tangga untuk mempresentasikan sebuah rumah.

Dalam proses penciptaan naskah dan pertunjukan teater Asera mengadopsi metode Hawkins (dalam Marianto et al., 1995:24) ke dalam wujud penciptaan teater dari ide, naskah lakon sampai kepada bentuk pertunjukan. Adapun yang dimaksud meliputi: (1) Eksplorasi: (a) penetapan tema, ide, dan judul karya; (b) berfikir, berimajinasi, merasakan, menanggapi dan menafsirkan tema terpilih. (2) Improvisasi: (a) memilih, membedakan, mempertimbangkan, menciptakan harmonisasi dan kontras-kontras tertentu, (b) menemukan integritas dan kesatuan dalam berbagai percobaan. (3) Perwujudan.

\section{Eksplorasi}

Eksplorasimerupakansuatubentukpenjajagan/ penjelajahan terhadap ide yang merupakan sumber dari penciptaan. Adapun langkah-langkah yang dilakukan sebagai berikut:

\section{Penetapan Tema, Ide, dan Judul Karya}

Pada tahap ini dilakukan penjajakan tentang kebenaran dan keberadaan dari mitos tersebut. Penulis mengumpulkan data dengan cara melihat langsung, wawancara serta membaca beberapa literatur bacaan yang relefan dengan kebenaran 
maupun keberadaan dari mitos tersebut. Tahapan ini digunakan untuk menemukan dan menetukan situasi absurd dalam memandang kematian pada mitos angka sembilan To Balo. Selanjutnya tema, ide dan judul karya dirumuskan sebagai hasil dari proses yang telah dilakukan.

\section{Berfikir, Berimajinasi, Merasakan, Menanggapi dan Menafsirkan Tema Terpilih ke Dalam Sebuah Naskah Lakon}

Pada tahap ini hasil penjajakan kemudian dieksplor melalui tahapan-tahapan; berfikir, berimajinasi, merasakan, menanggapi dan menafsirkan tema terhadap objek yang menjadi rangsangan awal yaitu, tentang situasi absurd dalam memandang kematian yang diatur oleh jumlah sembilan.

\section{Improvisasi}

Pada tahap improvisasi, di mana dilakukan transformasi naskah dari tangan penulis selanjutnya ke tangan sutradara yang diwujudkan dalam latihan menuju sebuah pertunjukan. Adapun langkahlangkah yang dilakukan berdasarkan adopsi dari metode improvisasi Alma M. Hawkins, adalah sebagai berikut:

\section{Memilih, Membedakan,}

\section{Mempertimbangkan, Menciptakan Harmonisasi dan Kontras-Kontras Tertentu}

Naskah lakon yang telah jadi pada tahap eksplorasi selanjutnya ditafsirkan (memilih, membedakan, mempertimbangkan, menciptakan harmonisasi dan kontras-kontras tertentu) berdasarkan tema, tokoh dan penokohan, setting cerita dan setting masalah yang selanjutnya digunakan sutradara untuk menerjemahkan bentuk teks naskah lakon menjadi tubuh, suara aktor dan suasana panggung, serta perancang artistik dalam merancang naskah menjadi elemen artistik pertunjukan.

\section{Menemukan Integritas dan Kesatuan dalam Berbagai Percobaan}

Mengujicobakandalamlatihanhasil terjemahan teks sastra menjadi teks seni pertunjukan kepada
Aktor dan penata artistik oleh sutradara. Pada tahap ini ditemukan integritas dan kesatuan setelah melakukan beberapa latihan sampai pada tahap hasil latihan sudah dirasakn layak untuk dipertunjukan.

\section{Perwujudan}

Pada tahap ini adalah menentukan bentuk ciptaan dengan menggabungkan unsur-unsur yang dihasilkan dari pelbagai percobaan dari latihan yang telah dilakukan sebelumnya. Pertunjukan Asera dikemas sebagai pertunjukan teater tentang absurditas, dengan mengedepankan esensi manusi dalam posisi absurd dalam menghadapi pemberontakan terhadap kematian. Mengutamakan situasi dan kedirian dari tokohtokohnya. Kematian menjadi sesuatu yang begitu terasa mencemaskan. Selanjutnya dari tangan Sutradara Stage manager, crew panggung, penata artisitik dan aktor menghadirkan naskah di atas panggung.

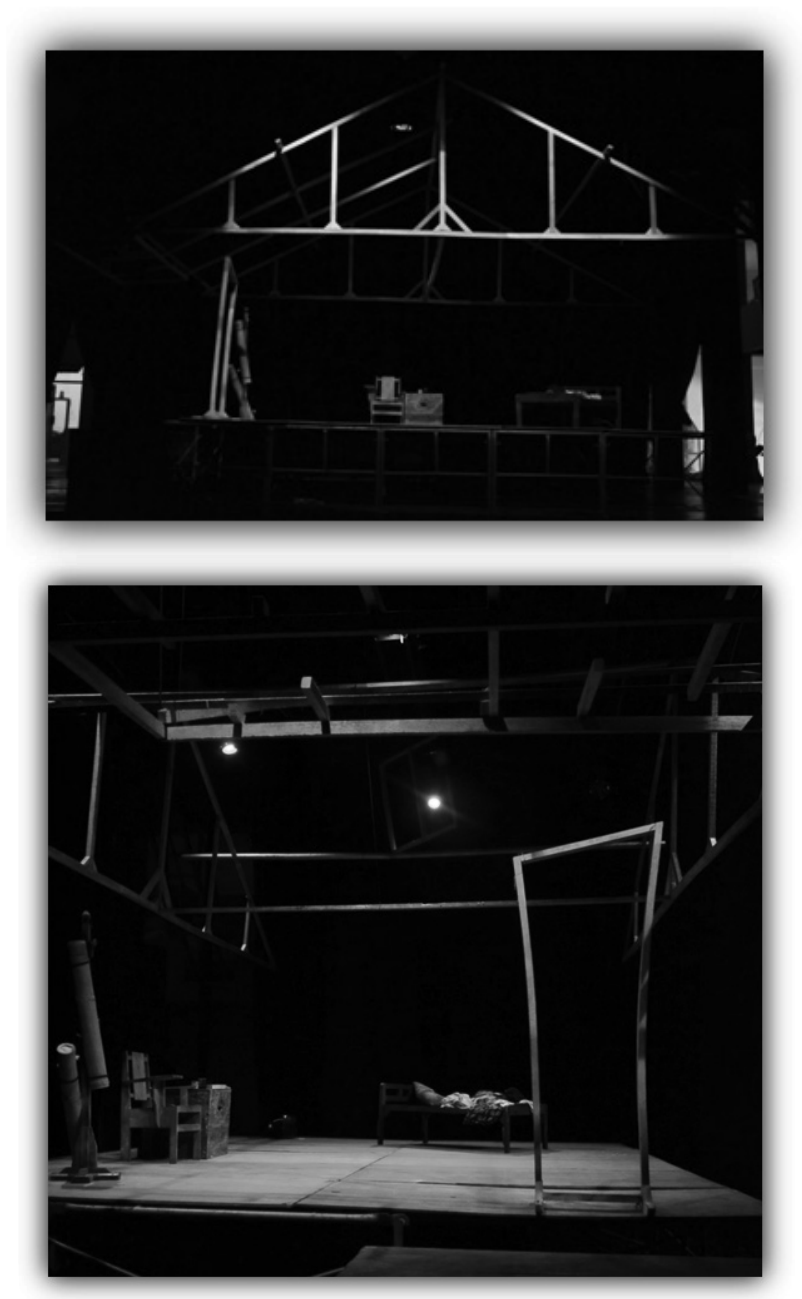




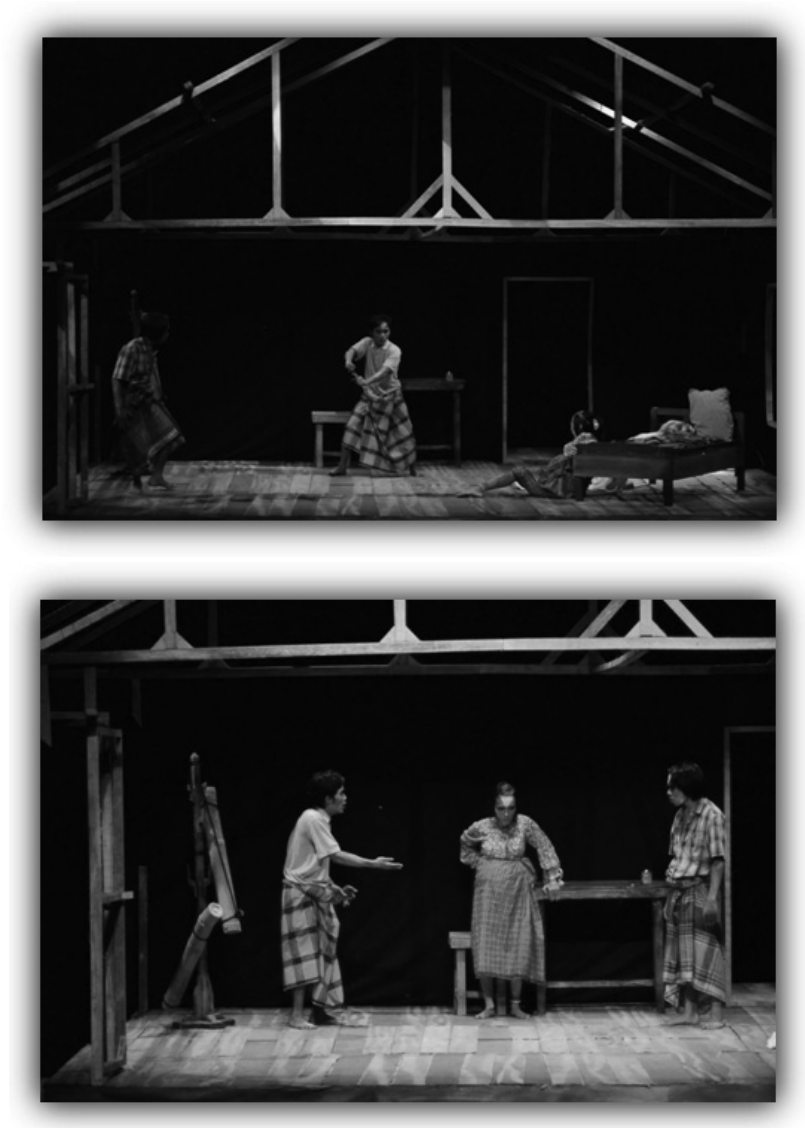

Gambar 6. Dokumentasi Pertunjukan Asera (Foto: Didit)

\section{Penutup}

Penulis yang juga sekaligus pencipta melakukan penciptaan mulai penulisan naskah drama Asera, hingga sampai pada pagelaran Asera. Menerjemahkan gagasan menjadi ide cipta, penulis menjadikan cerita mitos suku To Balo sebagai wahana bagi peristiwa yang di dalamnya terdapat visi untuk memperlihatkan sisi absurd manusia, yaitu kesunyian, kesepian, kecemasan yang diakibatkan pertarungan keinginan manusia dengan dunianya yang tidak selalu bisa menghadirkan segala hal yang diinginkan. Sebuah ide dari diri penulis yang terinspirasi dari kepercayaan mitos Asera mengubahnya menjadi sebuah peristiwa rekaan yang diwujudkan ke dalam naskah lakon berjudul Asera.

Pada saat mencipta naskah lakon Asera, penulis berupaya sebisa mungkin untuk lebih mengedepankan situasi dibandingkan peristiwanya. Tokoh-tokoh yang diciptakan melihat dirinya dari luar sebagai individu yang terasing dengan dunia dan lingkungannya, merasakan sensasi absurd. Naskah Asera adalah murni peristiwa rekaan yang berasal dari imajinasi penulis dengan visi estetikanya melihat keadaan dunia segala tawaran kecemasannya. Proses penulisan naskah Asera ini menjadi tahap yang paling penting pada keseluruhan proses cipta yang dilakukan penulis.

Penulis beralih dari kerja individu sebagai penulis naskah menuju kerja kolektif sebagai sutradara ketika menerjemahkan teks naskah lakon Asera ke teks pertunjukan Asera. Penulis menemukan beberapa hal yang mewarnai perjalanan proses ini, di antaranya kekurangankekurangan yang sebelumnya tidak ditemukan ketika hanya berbetuk teks naskah. Adanya masukan daribeberapa elemen pertunjukan, seperti aktor dan penata artisitk, menjadikan penulis kembali untuk merevisi naskahnya. Setting yang pada awalnya hanya berupa pintu dan kursi, pada akhirnya direvisi dengan menghadirkan ruangan utuh dalam sebuah rumah. Kemonotonan pada adegan pertama ditaktisi dengan memadatkan dialog dan men-cut dialog-dialog yang dianggap panjang dan tidak penting.

Sebagai sutradara, proses latihan Asera adalah proses untuk menurunkan ego. Hal ini sangat penting dilakukan ketika menemukan kendala yang memungkinkan menghambat jalannya proses latihan. Dari awal latihan sampai dengan pertunjukan, penulis tetap bersama dengan orang-orang yang memiliki komitmen untuk mewujudkan ide penulis ke dalam sebuah pertunjukan.

Folklor Indonesia memiliki kekayaan yang beraneka ragam, banyak dari folklor tersebut bisa dijadikan ide cipta seni untuk diwujudkan sebagai sebuah karya naskah dan pertunjukan teater. Mencipta naskah lakon dari ide mitos dan kepercayaan masyarakat, sebagai pencipta, kita bisa menemukan hal yang dianggap menarik dari mitos tersebut untuk dikembangkan menjadi peristiwa naskah. Menciptakan peristiwa, kita tidak mutlak harus berdasarkan peristiwa yang disediakan oleh mitos tersebut, kita bisa mencipta sebuah peristiwa baru dan tentunya dengan landasan yang jelas. Mewujudkan pertunjukan teater Asera adalah sebuah pekerjaan kolektif yang melibatkan beberapa orang. Menyatukan karakter yang berbeda dalam sebuah wadah. Cara menyatukan itulah yang menjadi sasaran awal sebelum kita melanjutkan visi kebersamaan untuk mewujudkan sebuah pertunjukan teater Asera. 


\section{Kepustakaan}

Anirun, Suyatna. 1998. Menjadi Aktor. Pengantar kepada Seni Peran untuk Pentas dan Sinema. Bandung: STB. 2002. Menjadi Sutradara. Bandung. STSI Press.

Bagus, Lorens. 2000. Kamus Filsafat. Jakarta: Gramedia.

Camus, Albert. 1999. Mite Sisifus: Pergulatan dengan Absurditas. Jakarta: Gramedia.

Danandjaja, James. 1987. Folklor Indonesia Ilmu Gosip, Dongeng dan Lain-lain. Jakarta: Pustaka Utama Grafiti.

Harymawan, RMA. 1993, Dramaturgi. Bandung: Remaja Rosdakarya.

Kernodle, R. George. 1967. Invatation to The Theatre. USA: Brace, \& World. Inc.

Longi, Syarief. 2003. Geliat di Kampung Budaya Barru: Yayasan LSM Sipurio,.

Muzairi. 2002. Eksistensialisme Jean Paul Sartre. Sumur Tanpa Dasar Kebebasan Manusia. Yogyakarta: Pustaka Pelajar.
O'donnel, Kevin. 2003. A Histories of Ideas atau Sejarah Ide-ide. Yogyakarta: Kanisius.

Riantiarno, N. 1993. Perjalanan Teater. Bandung: Studi Klub Teater.

Sartre, Jean Paul. 1960, Existensialism and Humanism. London: Mairet.

\section{Jakarta: Pt Sun.} 1972. Psikologi Imajinasi. Yogyakarta: Yayasan Bentang Budaya. . 1992. Being and Nothingness. Washington: Square Press,.

Soemanto, Bakdi. 2001. Jagat Teater. Yogyakarta: Media Press Indo.

Sudaryanto. 2004. "Objektivitas dan Subjektivitas Presentasi Seni" dalam Jurnal Filsafat Jilid 38 No.3. Desember.

Yudiaryani \& Hamdi Salad. 1997. Gagasangagasan Teater Garda Depan. Memahami Konsep Teater Antonin Artaud. Yogyakarta: Taman Budaya Yogyakarta,. 